\title{
The effect of company characteristics and auditor characteristics to audit report lag
}

\author{
Muhammad Rifqi Abdillah, Agus Widodo Mardijuwono and \\ Habiburrochman Habiburrochman \\ Department of Accounting, Fakultas Ekonomi dan Bisnis, \\ Universitas Airlangga, Surabaya, Indonesia
}

\begin{abstract}
Purpose - The purpose of this paper is to examine and analyze the factors that affect an auditor's efficiency in completing the audit process proxied by audit report lag. The factors used in this study are selected by looking at the characteristics of the company and the characteristics of an auditor.

Design/methodology/approach - Company characteristics were proxied by the audit committee effectiveness, financial condition, accounting complexity and profitability, whereas auditor characteristics were proxied with auditor reputation, audit tenure and auditors industry specialization. Populations of this study were all manufacturing companies listed in Indonesian Stock Exchange in 2014-2016. Based on the purposive sampling method, the number of samples obtained from 231 companies was 77 . Multiple linear regression method was used to analyze this study. Hypothesis testing was done by statistical $t$-test (partial). Findings - The results showed that partially variables of the audit committee effectiveness and profitability had a significant negative effect on audit report lag while the variable financial condition had a significant positive effect on audit report lag. Meanwhile, variables of the accounting complexity, auditor reputation, audit tenure and auditors' industry specialization did not show significant influence on audit report lag.

Originality/value - This study tests both company's and auditor's characteristic on audit report lag that as far as authors know never been tested simultaneously.
\end{abstract}

Keywords Audit committee effectiveness, Accounting complexity, Auditors characteristics,

Financial condition, Firms characteristics

Paper type Research paper

\section{Introduction}

Shareholders are entitled to obtain information on the financial condition and results of the company's operations. The information is used by the shareholders to evaluate the performance of the management and make a decision on whether the company is providing benefits or not to them. Therefore, the financial statements are a form of management accountability for the management of the entity's resources entrusted to it. In addition, the financial statements are also a means of communication of the management to shareholders. In order for the financial statements to be valuable to the user at the time of decision making, the financial statements should contain qualitative characteristics that are characteristic of financial statement information. The qualitative characteristics of financial statements based on the Basic Framework of Preparation and Presentation of Financial Statements of Financial Accounting Standards are understandable, relevant, reliable and comparable. Relevant qualitative and reliable qualitative characteristics are the primary quality characteristics of a financial report. The financial statements are said to contain

(c) Muhammad Rifqi Abdillah, Agus Widodo Mardijuwono and Habiburrochman Habiburrochman. Published in Asian Journal of Accounting Research. Published by Emerald Publishing Limited. This article is published under the Creative Commons Attribution (CC BY 4.0) licence. Anyone may reproduce, distribute, translate and create derivative works of this article (for both commercial and non-commercial purposes), subject to full attribution to the original publication and authors. The full terms of this licence may be seen at http://creativecommons.org/licences/by/4.0/legalcode

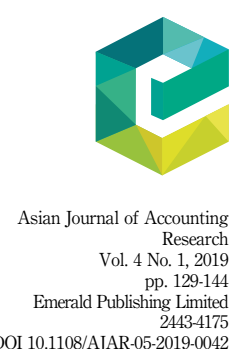


AJAR

4,1

relevant information if the financial statements have the ability to influence the decision of the manager or users of the financial statements so that the existence of the financial statements is able to alter or support their expectations about the results or consequences of the action taken.

Delivery timeliness of financial statements to the public is essential to maintaining the relevance of information in the financial statements. Due to inadvertent delays in the delivery of financial statements, the information generated in the financial statements will lose the ability to influence user decisions (Praditya dan Fitriany, 2013). For investors, the timely delivery of financial statements will reduce uncertainty in investment decision making (Ashton et al., 1989) and the dissemination of asymmetric information among investors in the capital market (Jaggi and Tsui, 1999). Timely delivery of financial statements will help to reduce the occurrence of leak, rumors and insider trading in the stock market (Owusu-Ansah, 2000). Timeliness of financial statement submission also provides valuable information for shareholders in the decision-making process (Al-Ajmi, 2008).

Therefore, the Capital Market and Financial Institution Supervisory Agency (Bapepam and LK) make regulations regarding the deadline for submitting financial statements. The role of Bapepam and LK was replaced by the Financial Services Authority (OJK) starting on October 27, 2011 in Law No. 21 of 2011. The regulation governing the deadline for submission of annual financial statements of an issuer or a public company shall be the Decision of the Chairman of the Capital Market Supervisory Agency Number KEP-346/BL/ 2011. In Rule Number XK2 stating the annual financial statements shall be presented comparative with the same period of the previous year, shall be accompanied by an accountant's report in the context of an audit of the financial statements and shall be submitted to Bapepam and LK and announced to the public no later than the end of the third month after annual finance report. However, for companies whose shares are listed on the Foreign Exchange, the date of submission of the financial statements follows the date set by the Foreign Exchange.

However, the timeliness of the delivery of financial statements in accordance with the prevailing regulations is confronted with obstacles, one of which is that financial statements should be audited by independent public accountants. The timeliness of the delivery of financial statements depends on the period of completion of the audit process. This is because the financial statements cannot be published before the audit is completed (Johnson, 1998).

In the process of completion of the audit, the auditor must comply with the auditing standards set by the Public Accountant Association. One of the auditing standards that must be met by an independent auditor is the Standards of Field Work. In addition, in the implementation of the auditing standards, the auditor should also consider the audit risk to be faced. Therefore, for the fulfillment of audit pelakasanaan according to standard and because of audit risk encountered auditors require a longer time in the process of completion of the audit so that this will impact on the timeliness of financial reporting. Essentially, the timeliness of audit task completion indicates that the auditor should work efficiently without overriding the reliability of the information generated in the financial statements.

This study aims to determine the factors that affect the efficiency of time in the assignment. Researchers produced time efficiency in the assignment by using an audit report lag. Understanding of the factors affecting the audit report lag will likely provide an understanding of the efficiency of time in audit assignments (Habib and Bhuiyan, 2011). Some previous reports of audit report lag are often called auditors' signature or audit delay. Al-Ajmi (2008) defines auditors' signature lag, i.e., the number of days starting from the closing date of the company's book until the auditor's signature date in the audit report after the auditor makes an opinion regarding the company's financial statements. 
The factors that affect audit report lag have been examined by some previous research studies, they have been examined in the country and abroad. Related to these research studies, researchers choose factor or variable that influences audit report lag by looking from the side of company characteristic and auditor characteristic. Previous research has shown that factors affecting the length of audit report lag are related to corporate characteristics, such as industry size, the presence of extraordinary items, etc. (Ashton et al., 1989), and auditor characteristics, such as the breadth of the auditor's work, the experience of the audit staff, the auditor's insensitiveness and tenure audit (Bamber et al., 1993). This study focused on factors derived from firm characteristics and auditor characteristics. This is because the main factor causing the length of audit report lag comes from within the two entities. Each company (auditee) has different characteristics so that the risks faced and procedures used by the auditor will also be different while the auditor as the executor also has different skills and expertise in conducting a corporate audit.

Corporate characteristic factors that influence audit report lag include the effectiveness of the audit committee, accounting complexity, financial condition and profitability. The researcher chooses the firm characteristic factors based on the auditor's responsibilities and the testing procedures that the auditor must perform during audit assignments such as non-substantive and substantive testing.

In addition to factors from the side of the company that affect audit report lag, factors from the auditor's side also influence the report lag. Auditor characteristic factors that affect audit report lag include auditor reputation, audit tenure and auditor industry specialization.

The remainder of this paper is structured as follows. Section 2 develops the literature review. Section 3 describes the research methodology. Section 4 specifies the empirical results. Section 5 discusses results and Section 6 summarizes the paper and presents concluding remarks.

\subsection{Research problems}

Based on the background described earlier, the issues discussed in this research are:

(1) Corporate characteristics consisting of the effectiveness of the audit committee, financial condition, accounting complexity and profitability affecting audit report lag; and

(2) Auditor characteristics consisting of auditor reputation, audit tenure and industry specialization affecting audit report lag.

\section{Literature review}

Agency theory provides an explanation of the agency relationship; it is the relationship between the owners of the company or shareholders as a principal with the management company as an agent. In the agency relationship, there is a contract between one or more persons domiciled with another person who is an agent to perform a work in accordance with the principal's interests, accompanied by the delegation of decision-making authority to the agent (Jensen and Meckling, 1976). This agency theory is motivated by the existence of principals or shareholders who are not possible to carry out all the functions required in the management of a company due to the limited ability, time, etc., so that the principal appoints the agent of company management to replace the task of managing the company's activities (Sudana, 2011). The existence of a conflict of interest between the agent and the principal can lead to the asymmetry of information that is the imbalance of information owned by both parties where the agent has more information than the principal about the company. This is because management as a party has more 
AJAR

4,1

132

detailed information about the company to hold or not provide perfect information to the shareholders because it is more profitable for management.

\section{Research methodology}

\subsection{Operational definitions}

3.1.1 Audit report lag. Audit report lag is the length of days required by the auditor to complete the audit process of the company's financial statements after the closing date of the company's books (Carslaw and Kaplan, 1991; Bamber et al., 1993). The lag report audit is measured by counting the number of days after the closing date of the company's book (January 1) up to the date of signing of the independent auditor's report (LAI) by the auditor stated in the company's audited financial statements.

3.1.2 The effectiveness of the audit committee. The effectiveness of the audit committee is an audit committee that qualifies members with the authority and resources to protect the interests of stakeholders by ensuring the reliability of financial reporting, internal control and risk management, as well as through diligent monitoring. This variable is measured by summing the scores of the committee effectiveness index built by DeZoort et al. (2002). The index consists of four elements, namely, composition, authority, resources and persistence, which are then divided into ten requirements. Higher scores indicate that audit committees are more effective. The measurement of the effectiveness of variables of the audit committee are described in Table I.

3.1.3 Financial condition. The probability of bankruptcy is used as a proxy in assessing a company's financial condition as measured using the Zmijewski Model (Habib and Bhuiyan, 2011). The Zmijewski Model is based on several financial ratios: return on assets (ROA) (net income/total assets), financial leverage (total debt/total assets) and liquidity (current assets/current debt). The formula of Zmijewski Model is as follows:

\begin{tabular}{|c|c|c|c|}
\hline Dimensions & Proxy & Score & Source \\
\hline Composition & $\begin{array}{l}\text { Independence } \\
\text { All members are independent external parties } \\
\text { Expertise } \\
\text { At least one member has educational background and } \\
\text { expertise in accounting or finance }\end{array}$ & $\begin{array}{l}1: \text { if it meets the } \\
\text { requirements } \\
0: \text { does not meet the } \\
\text { requirements }\end{array}$ & $\begin{array}{l}\text { Ika dan } \\
\text { Ghozali }\end{array}$ \\
\hline Resources & $\begin{array}{l}\text { Audit committee size } \\
\text { The number of audit committees has at least three members }\end{array}$ & $\begin{array}{l}\text { 1: if it meets the } \\
\text { requirements } \\
0: \text { does not meet the } \\
\text { requirements }\end{array}$ & $\begin{array}{l}\text { Ika dan } \\
\text { Ghozali }\end{array}$ \\
\hline Authority & $\begin{array}{l}\text { Charter of the Audit Committee } \\
\text { Proxy reports relating to audit committee charter } \\
\text { The assignment of responsibilities } \\
\text { a. Supervise the company's financial information } \\
\text { b. Supervise the activities of external auditors } \\
\text { c. Overseeing the effectiveness of corporate internal control } \\
\text { d. Oversee the company's compliance with the rules }\end{array}$ & $\begin{array}{l}\text { 2: if explaining in } \\
\text { detail } \\
\text { 1: a brief statement } \\
0 \text { : do not reveal at all }\end{array}$ & $\begin{array}{l}\text { Ika dan } \\
\text { Ghozali }\end{array}$ \\
\hline Perseverance & $\begin{array}{l}\text { Meeting } \\
\text { Intensity of meeting at least four times in one-year } \\
\text { Voluntary disclosure } \\
\text { There is a voluntary disclosure report of the audit committee }\end{array}$ & $\begin{array}{l}1 \text { : if it meets the } \\
\text { requirements } \\
0 \text { : does not meet the } \\
\text { requirements }\end{array}$ & $\begin{array}{l}\text { Ika dan } \\
\text { Ghozali }\end{array}$ \\
\hline
\end{tabular}

Table I.

Measurement of the effectiveness of the audit committee

$$
\mathrm{ZFC}=-4.336-4.513(\mathrm{ROA})+5.679(\mathrm{FINL})+0.004(\mathrm{LIQ}) .
$$


From the Zmijewski Model, if the higher ZFC value indicates the higher the level of bankruptcy or financial failure of the company that raises the risk of high audit so increasing ARL.

3.1.4 Complexity of corporate accounting. Accounting complexity is the complexity of the accounting process that occurs in an enterprise caused by the company, which has several segments or subsidiaries that operate. In accordance with Sengupta (2004) and Al-Ajmi (2008) studies, accounting complexity was measured using dummy variables. If the firm reports more than one major segment, it gets a score of 1 , vice versa if the company only reports one major segment, then scores 0 .

3.1.5 Profitability. Profitability is the company's ability to generate profits using company-owned resources, such as company assets. Profitability is measured by using profitability ratio, i.e., ROA. The greater ROA of the company gains shows the more efficient use of company assets to generate profits. In this study, ROA is formulated as follows:

$$
\mathrm{ROA}=\text { Net income/Total assets. }
$$

3.1.6 Auditor reputation. The reputation of the auditor (KAP) is a public trust that is held by the auditor (KAP) on behalf of the big one it has. The auditor's reputation is divided into two major groups: Big Four and Non-Big Four KAP. Auditor reputation variables are measured using dummy variables. Companies that are audited by the Big Four will be scored 1, whereas companies audited other than the Big Four will be scored 0 .

3.1.7 Tenure audit. Tenure audit is the length of the engagement period between the auditor (KAP) and the auditee associated with the use of audit services that have been agreed on an ongoing basis without any change with the other auditors. In identifying the appropriate audit tenure, caution and compliance with applicable regulations are required. This is related to the existence of the problem of KAP rotation in pseudo where there is a rotation of KAP but substantially KAP is still the same KAP. Therefore, in this study measuring the audit tenure only uses real rotation. This is because of the experience and understanding of the auditor to the client in accordance with the duration of the provision of audit services in real terms.

3.1.8 Specialization industrial auditor. The auditor that specialists say is an auditor who has a specific understanding of a particular industry that causes them to gain a more comprehensive understanding of the industry's characteristics (Maletta and Wright, 1996; Owhoso, 2002). Specialist auditors are measured using dummy variables. The industry-specific auditor will be given a score of 1 while a score of 0 is given to auditors who do not have an industry specialization.

The measurement of auditor industry specialization refers to the research of Gul et al. (2009) using the market share approach. The approach can be identified by using the percentage of total assets of a company audited by a firm in a particular industry. The formula of the approach model is as follows:

$\mathrm{SPEC}=\frac{\text { Jumlah Klien KAP dalam Industri }}{\text { Jumlah Seluruh Emiten dalam Industri }} \times \frac{\text { Rerata Aset Klien KAP dalam Industri }}{\text { Rerata Aset Seluruh Emiten dalam Industri }}$

From the above formula, the auditor is said to have an industry specialization if the SPEC amount is equal to or greater than 30 percent, according to Reichelt and Wang (2009) research.

\subsection{Types and data sources}

The type of data used in this study is quantitative data. Quantitative data are data in the form of numbers. Due to its shape, these data can be processed and analyzed using 
AJAR

4,1

134

mathematical calculation techniques or statistics. In this research the data source is secondary data. In this study the required data are data in audited financial statements (audited financial report) and annual report (annual report) of a company during the period 2014-2016, obtained from the website of Indonesian Stock Exchange (www.idx.co.id).

\subsection{Method of collecting data}

Prior to conducting the research, the researcher must design how the procedures or steps are performed to collect the data. Data are collected from data sources. Due to data source use secondary data that are data in audited financial report (audited financial report) and company annual report; hence, the method of collecting data used in this research is the method of documentation. Researchers see the document in the form of audited financial statements (audited financial report) and the annual report of the company.

\subsection{Data analysis technique}

The analysis technique used in this research is multiple linear regression analysis which is used to know the influence of independent variables (effectiveness of audit committee, financial condition, accounting complexity, profitability, auditor reputation, audit tenure and auditor industry specialization) to dependent variable (audit report lag). A statistical model is widely used to examine the relationship of influence between the dependent variable and the independent variable. In this study, statistical calculations done by using the Statistics Packages For Social Science (SPSS) version 20 program are as follows:

$$
\begin{aligned}
\mathrm{ARL}_{i, t}= & \alpha+\beta_{1} \mathrm{ACEFEC}_{i, t}+\beta_{2} \mathrm{ZFC}_{i, t}+\beta_{3} \mathrm{SUBS}_{i, t}+\beta_{4} \mathrm{ROA}_{i, t} \\
& +\beta_{5} \mathrm{REP}_{i, t}+\beta_{6} \mathrm{TEN}_{i, t}+\beta_{7} \mathrm{ASI}_{i, t}+\Sigma_{i, t} .
\end{aligned}
$$

The regression model in this study is as follows:

$\mathrm{ARL}_{i, t}=$ audit report lag; $\alpha=$ intercept; $\mathrm{ACEFEC}_{i, t}=$ effectiveness of the audit committee; $\mathrm{ZFC}_{i, t}=$ financial condition; $\mathrm{SUBS}_{i, t}=$ accounting complexity; $\mathrm{ROA}_{i, t}=$ profitability; $\mathrm{REP}_{i, t}=$ auditor reputation; $\mathrm{TEN}_{i, t}=$ tenure audit; $\mathrm{ASI}_{i, t}=$ industry specialization of auditors; $\Sigma_{i, t}=$ size of error for company.

In addition, this research uses techniques such as:

(1) Descriptive statistics, which results from descriptive statistics for the variables used are presented in descriptive statistics tables in the form of maximum values, minimum values, mean values and standard deviation values.

(2) Test classical assumptions such as normality, multicollinearity, heteroscedasticity and autocorrelation. They are used in this study and can provide representative results (BLUE: best, linear, unbiased, estimator).

(3) Testing the hypothesis with $t$-test. $t$-Test is conducted to test whether or not the influence of independent variables to the dependent variable is partially. The test is univariate by using $t$-test method. Determination level is of 5 percent.

(4) The coefficient of determination is essentially used to measure the model's ability to explain the variation of the dependent variable (Ghozali, 2009).

\section{Results}

\subsection{Description of research variables}

(Table II). 
4.2.1 Normality test. Based on Figure 1, it appears that the data spread around the diagonal line and follow the direction of the diagonal line. Thus, it can be concluded that the P-P plot graph shows the data are normally distributed.

4.2.2 Multicollinearity test. Based on Table III it is known that all independent variables (effectiveness of the audit committee (ACEFEC), bankruptcy probability (ZFC), accounting complexity (SUBS), profitability (ROA), auditor reputation (REP), tenure audit (TEN) and industry) have a tolerance value $>0.1$ and VIF $<10$. It can be concluded that all independent variables in the regression model tested in this study did not occur multicollinearity.

4.2.3 Heteroscedasticity test. The scatterplot diagram in Figure 2 shows that spreading dots do not accumulate and do not form a distinctive pattern. Thus, it can be concluded that the results of this test state that the regression model is free from symptoms of heteroskedastisitas or homoskedastisitas occur.

4.2.4 Autocorrelation test. Based on the Durbin-Watson test presented in Table IV, the regression for Equation (1) shows the value of 1.687, which means that the Durbin-Watson value is still in the range of autocorrelation-free regions as they are between -2 to +2 .

\begin{tabular}{lccccc}
\hline & $n$ & Min. & Max. & Mean & SD \\
\hline ARL & 231 & 40 & 151 & 78.15 & 15.750 \\
ACEFEC & 231 & 4 & 14 & 10.55 & 2.724 \\
ZFC & 231 & -4.8192 & 12.9049 & -1.794143 & 2.4232024 \\
ROA & 231 & -0.1611 & 0.4317 & 0.063125 & 0.0900350 \\
TEN & 231 & 1 & 6 & 2.41 & 1.518
\end{tabular}

Valid $n$ (listwise)

231

Source: Processed results of SPSS data

Table II.

Descriptive statistics

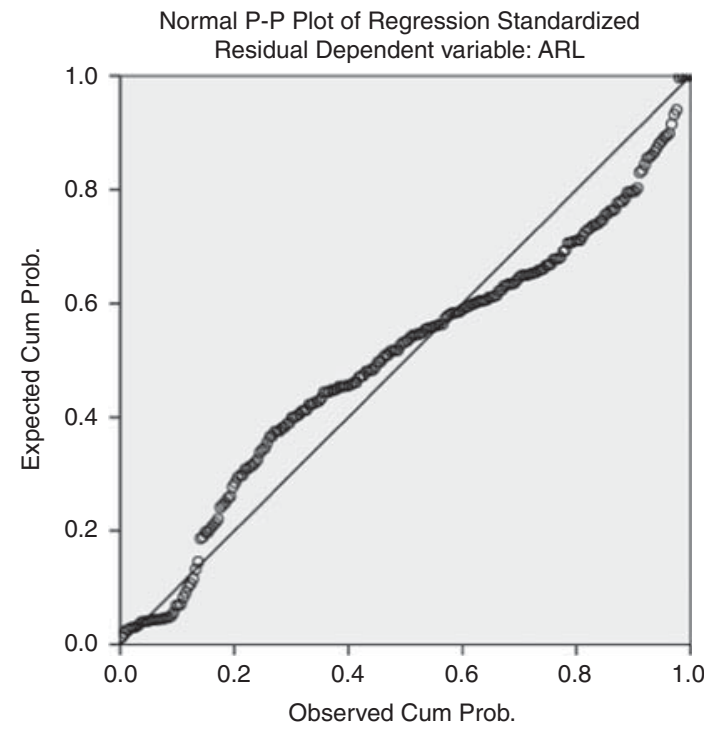

Source: Processed results of SPSS data
Figure 1. Normality test chart 


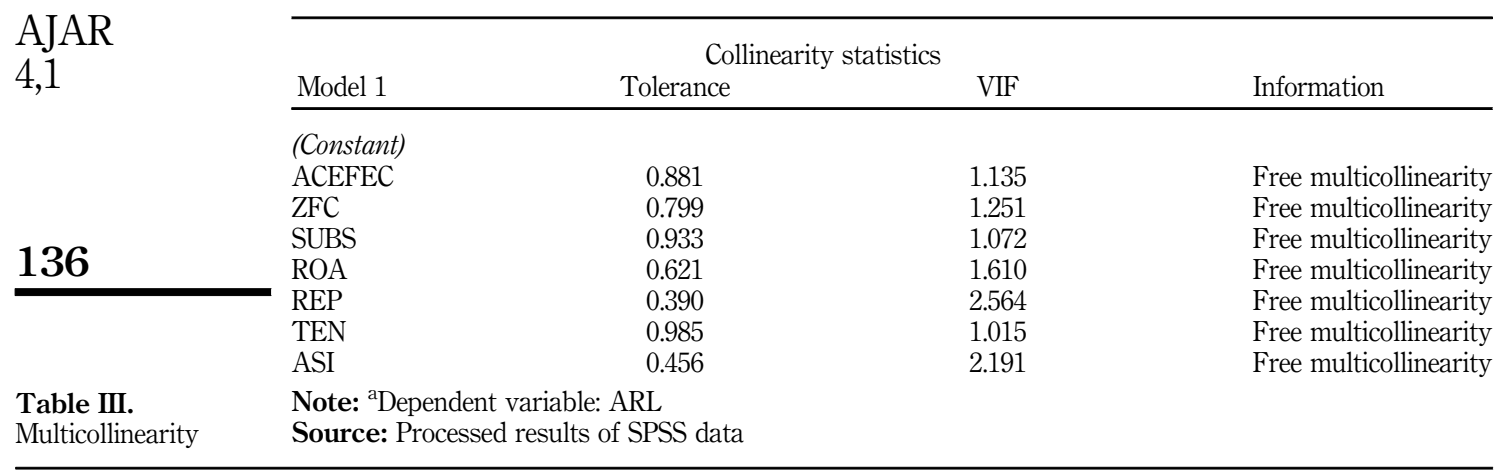

Figure 2.

Heteroscedasticity test

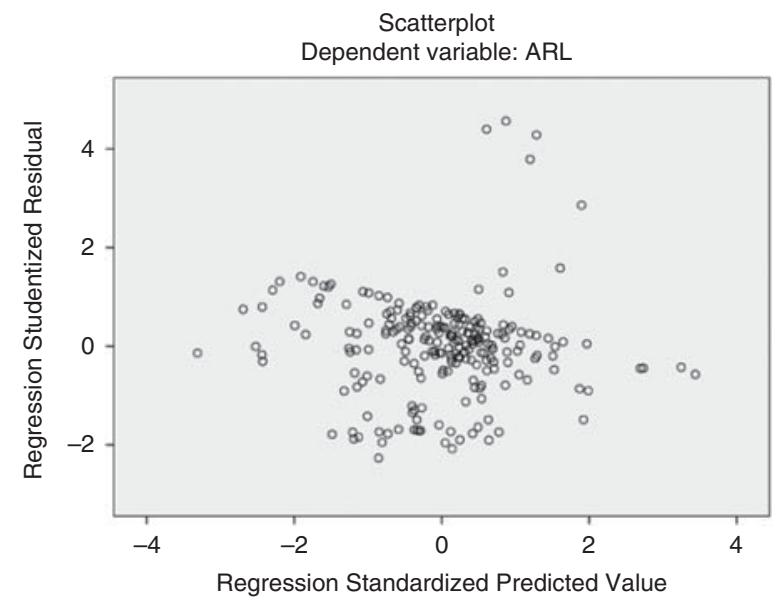

Source: Processed results of SPSS data
Table IV.

Autocorrelation results
Model summary ${ }^{\mathrm{b}}$

Model Durbin-Watson

1

1.678

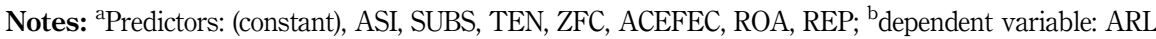

Source: Processed output results of SPSS data

\section{3 t-Test}

(Table V).

\subsection{F-test}

From Table VI it is concluded that the estimated linear regression model is feasible to be used to explain the effect of all independent variables on dependent variable. 


\begin{tabular}{|c|c|c|c|c|}
\hline \multirow[b]{2}{*}{ Model 1} & \multicolumn{4}{|c|}{ Coefficients $^{\mathrm{a}}$} \\
\hline & Coefficient & $t$ & Sig. & Conclusions \\
\hline (Constant) & 86.725 & 18.667 & 0.000 & \\
\hline ACEFEC & -0.660 & -1.694 & $0.092 * *$ & Significant \\
\hline $\mathrm{ZFC}$ & 0.888 & 1.931 & $0.055^{* *}$ & Significant \\
\hline SUBS & 2.210 & 0.952 & 0.342 & No sig. \\
\hline ROA & -31.146 & -2.219 & $0.028^{*}$ & Significant \\
\hline REP & -2.324 & -0.704 & 0.482 & No sig. \\
\hline TEN & 0.291 & 0.441 & 0.660 & No sig. \\
\hline ASI & 2.066 & 0.594 & 0.553 & No sig. \\
\hline
\end{tabular}

Notes: ${ }^{2}$ Dependent variable: ARL. *** Significant at 5 and 10 percent significance levels, respectively Source: Processed output results of SPSS data

Table V.

Statistical results of $t$-test

\begin{tabular}{lccccc}
\hline & \multicolumn{2}{c}{ ANOVA $^{\text {a }}$} & & \\
Model 1 & Sum of squares & df & Mean square & $F$ & Sig. \\
\hline Regression & $6,183.678$ & 7 & 883.383 & 3.872 & $0.001^{\text {b }}$ \\
Residual & $50,872.019$ & 223 & 228.126 & & \\
Total & $57,055.697$ & 230 & & & \\
Notes: & 'Dependent variable: ARL; bredictors: (constant), ASI, SUBS, TEN, ZFC, ACEFEC, ROA, REP \\
Source: Processed output results of SPSS data
\end{tabular}

Table VI. Test results of $F$-test

\subsection{Determination coefficient test}

In Table VII, the value of $R^{2}$ of 0.108 indicates that the effectiveness of the audit committee, probability of bankruptcy, accounting complexity, profitability, auditor reputation, audit tenure and auditor industry specialization are able to explain variations in audit report lag by 0.108 or 10.8 percent; the remaining 0.892 or 89.2 percent is explained by other variables outside the independent variables used in the study.

\section{Discussion}

\subsection{The effect of the effectiveness of the audit committee on audit report lag}

The audit committee is part of the corporate governance component of the company proven to reduce audit report lag. There are several reasons that are suspected to underlie this. First, the audit committee can perform the task of overseeing the financial reporting process effectively. The audit committee can encourage the management of the company to be able to deliver the financial statements in a timely manner. Second, the audit committee has an important role in the effectiveness of the company's internal controls so that the more effective the audit committee the more effective the internal control of the company. The effective impact of internal controls is the decrease in substantive testing conducted by the auditor due to low risk control so that it can reduce audit report lag. Third, the audit

\begin{tabular}{lcccc}
\hline & \multicolumn{4}{c}{ Model summary $^{\mathrm{b}}$} \\
Model & $R$ & $R^{2}$ & Adjusted $R^{2}$ & SE of the estimate \\
\hline 1 & $0.329^{\mathrm{a}}$ & 0.108 & 0.080 & 15.104
\end{tabular}

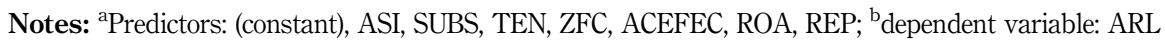

Source: Processed output results of SPSS data

Table VII.

Coefficient determination test results 
AJAR

4,1

committee also has a role to ensure that external audits are running effectively by considering several factors, including independence, scope of assignment, cost efficiency and objectivity of the external auditor.

\subsection{The influence of financial condition on report lag audit}

Companies that are experiencing financial difficulties tend to experience longer audit lag reports. It is hoped that a company with a weak financial condition will pose a greater audit risk of giving an opinion in accordance with the company's financial condition. To reduce the audit risk, the auditor will expand its audit procedures so that this will cause the auditor to take longer time in the audit process. In addition, companies with the weak financial condition will have problems in terms of going concern, while the auditor is also responsible for evaluating his or her going concern auditee. Therefore, audit report lag will be longer if the company is experiencing a weak financial condition or going concern problem. Auditors will more often discuss and negotiate with their clients to find out management plans in the face of going concern corporate issues. Not only that, the auditor is also obliged to evaluate the effectiveness of the management plan in solving the problem going concern company.

\subsection{The influence of accounting complexity to audit report lag}

This study did not find any significant effect between variables accounting complexity proxied with reporting of company segment to audit report lag. The initial hypothesis argues that firms with high accounting complexity (having more than one major segment) will result in high levels of audit complexity and audit risk so that it will make the auditor take longer time in the audit process. However, such matters can be anticipated by the auditor with careful preparation in the early stages of auditing and an organized schedule so as to reduce the audit time budget. In addition, firms with high accounting complexity are also supported by good internal controls so that the audit risk issues generated will decrease. With good internal controls to make the control risk will decrease the automatic audit risk will also be reduced so that it can reduce the length of audit report lag.

\subsection{The effect of profitability on audit report lag}

The results of this study indicate that the higher the profitability obtained by a company, the shorter will be the audit report lag, vice versa. This is in accordance with the signal theory that companies that have good information (goodnews) will give a positive signal to the public that is by way of delivering financial statements as soon as possible. If the profitability of a company is higher, then the financial statements produced by the company will contain good news (goodnews). This is because companies that obtain high profitability indicate the success of the company's performance in managing its resources. The existence of good news encourages the company to ask the auditor to complete the audit process immediately so that the good news can be quickly conveyed to the shareholders or investors so that it will impact on increasing the value of the company. On the other hand, audit report lag will be longer if the company profitability is low. This is because low profitability is bad news that will have a negative impact on the value of the company such as a bad reaction of shareholders or investors that allow the impairment of corporate value. To avoid such things, companies will slow down to publish financial reports to the public. The company will ask the auditor to schedule a slower-than-expected audit process that will extend the audit report lag. 
In addition, firms with low profitability (losses) also have greater audit risk because they are likely to be the cause of financial distress or fraud, thus making the auditor to expand its audit procedures. This will lead to longer audit lag reports.

\subsection{The influence of the auditor's reputation of report lag's audit}

This research did not find any significant influence between auditor reputation variable to audit report lag. There are several reasons underlying those results. First, it relates to reputation and credibility. Big Four's KAP in terms of protecting reputation and credibility is by convincing stakeholders that they meet all disclosure requirements rather than prioritizing to complete the audit process as soon as possible. Therefore, this study shows that firms audited by the Big Four KAP do not result in a faster audit report lag than companies audited by the Non-Big Four KAP.

Second, many local Non-Big Four KAPs cooperate with other international KAPs, such as Paul Hadiwinata, Hidajat, Arsono, Achmad, Suharli; and partners affiliated with PKF, Amir Abadi Jusuf, Aryanto, Mawar \& Rekan; affiliated with RSM Tanubrata Sutanto Fahmi Bambang; affiliated with BDO, Doli, Bambang, Sulistiyanto, Dadang and Ali; affiliated with BKR, Mirawati Sensi Idris; affiliated with Moore Stephens, and so on. This makes local KAP not much different from Big Four's KAP in terms of resources and technology so audit report lag between KAP Big Four and Non-Big Four does not show any difference.

Third, in line with the increasingly fierce competition in the business world, all KAPs, both those with the Big Four and Non-Big Four, wish to retain their respective clients by working effectively and efficiently in completing the audit process so that audit report lag between Big KAP Four and Non-Big Four shows no significant difference.

\subsection{The effect of audit tenure on audit report lag}

This research indicates that audit tenure has no significant negative effect on audit report lag. This is because all auditors (KAP) are required to work professionally in completing the audit process in a timely manner so as not to harm the stakeholders who want to use the financial statements as a means for decision making. It is also in accordance with the theory of compliance (compliance theory) that it becomes imperative for an individual or organization such as an auditor to complete the audit process in a timely manner in accordance with applicable regulations. This is because the regulation has the authority to dictate or regulate the behavior of individuals or organizations.

In addition, this study is limited to tenure auditors proxied with KAP tenure without considering individual auditor tenure, while the implementation of the audit process of financial statements conducted by an auditor or partner of a KAP so that the long audit engagement between the KAP and the client does not indicate a long audit tenure for an auditor. This is also supported by the regulation stipulating that the auditor audits the auditor for the longest time in three consecutive years. Therefore, the results of this study conclude that longer audit tenure does not make the audit report lag shorter, vice versa.

\subsection{The influence of auditor industry specialization to audit report lag}

This study did not find any significant influence between the variables of industry auditor specialization on audit report lag. This is because the auditor's specialization status cannot be explicitly identified. According to some sources, there are different methods of determining industry specialization. Gramling and Stone (2001) and Dunn and Mayhew (2004) define industry specialization by referring to the market share identified through the sale of a company to a particular industry, while Balsam et al. (2003) determine industry specialization with reference to the number of clients in an industry. On the contrary, Gul 
AJAR

4,1

140

et al. (2009) identifie industry specialization with reference to the total assets of the client company. In addition, the auditor industry specialization can also be identified through auditing fees as used by Habib and Bhuiyan (2011). Therefore, any discrepancies in the method will result in the absence of consistency over the test results of the auditor industry specialization on any method used. This study of industry specialization is determined by using a market share approach that can be identified through the percentage of total assets of a company audited by a firm's KAP in a particular industry. The auditor is said to have an industry specialization if the SPEC amount is equal to or greater than 30 percent. These calculations resulted two KAPs belonging to have industry specialization, and the two KAPs are EY and PWC. It is alleged that the cause was not found to be significantly the result of testing the influence of audit industry specialization on audit report lag.

\section{Conclusion}

(1) The effectiveness of the audit committee has a significant negative effect on the audit report lag.

(2) Financial condition has a significant positive effect on the audit report lag.

(3) Accounting complexity does not affect audit report lag.

(4) Profitability has a significant negative effect on audit report lag.

(5) The auditor's reputation has no effect on audit report lag.

(6) Tenure audit has no effect on audit report lag.

(7) The auditor industry specialization has no effect on audit report lag.

\subsection{Suggestions}

Based on the results of research that has been done, suggestions for further research are:

(1) The value of $R^{2}$ in this study is still too low that is equal to 0.108 or indicates that the variables used in the study are able to explain variations audit report lag by 0.108 or 10.8 percent while the rest 0.892 or 89.2 percent explained by other variables outside variables used in the study. Therefore, for the next researcher it is suggested to replace or add another independent variable to get higher $R^{2}$ value.

(2) It is better for the next researcher to use the sample of the research not only in the manufacturing company so that the results obtained have a wider scope.

Based on the results of the calculation of the specific auditor only two KAPs are obtained, it is advisable for further researchers to use different measurement methods if still using this variable and the same sample with this research in order to show better results.

\section{References}

Al-Ajmi, J. (2008), "Audit and reporting delays: evidence from an emerging market", Advances in Accounting, Vol. 24 No. 2, pp. 217-226.

Ashton, R.H., Graul, P.R. and Newton, J.D. (1989), "Audit delay and the timeliness of corporate reporting”, Contemporary Accounting Research, Vol. 5 No. 2, pp. 657-673.

Bamber, E.M., Bamber, L.S. and Schoderbek, M.P. (1993), "Audit structure and other determinants of audit report lag: an empirical analysis", Auditing, Vol. 12 No. 1, p. 1.

Balsam, S., Krishnan, J. and Yang, J.S. (2003), “Auditor industry specialization and earnings quality”, Auditing: A Journal of Practice \& Theory, Vol. 22 No. 2, pp. 71-97. 
Carslaw, C.A. and Kaplan, S.E. (1991), "An examination of audit delay: further evidence from New Zealand”, Accounting and Business Research, Vol. 22 No. 85, pp. 21-32.

DeZoort, F.T., Hermanson, D.R., Archambeault, D.S. and Reed, S.A. (2002), "Audit committee effectiveness: a synthesis of the empirical audit committee literature", Journal of Accounting Literature, Vol. 21, pp. 38-75.

Dunn, K.A. and Mayhew, B.W. (2004), "Audit firm industry specialization and client disclosure quality", Review of Accounting Studies, Vol. 9 No. 1, pp. 35-58.

Ghozali, I. (2009), Aplikasi Analisis Multivariate Dengan Program SPSS, Badan Penerbit Universitas Diponegoro, Semarang.

Gramling, A.A. and Stone, D.N. (2001), "Audit firm industry expertise: a review and synthesis of the archival literature", Journal of Accounting Literature, Vol. 20 No. 1.

Gul, F.A., Fung, S.Y.K. and Jaggi, B. (2009), "Earnings quality: some evidence on the role of auditor tenure and auditors' industry expertise", Journal of Accounting and Economics, Vol. 47 No. 3, pp. 265-287.

Habib, A. and Bhuiyan, M.B.U. (2011), "Audit firm industry specialization and the audit report lag", Journal of International Accounting, Auditing and Taxation, Vol. 20 No. 1, pp. 32-44.

Jaggi, B. and Tsui, J. (1999), "Determinants of audit report lag: further evidence from Hong Kong", Accounting and Business Research, Vol. 30 No. 1, pp. 17-28.

Jensen, M.C. and Meckling, W.H. (1976), "Theory of the firm: managerial behavior, agency costs and ownership structure", Journal of Financial Economics, Vol. 3 No. 4, pp. 305-360.

Johnson, L.E. (1998), "Further evidence on the determinants of local government audit delay", Journal of Public Budgeting, Accounting \& Financial Management, Vol. 10 No. 3, pp. 375-397.

Maletta, M. and Wright, A. (1996), "Audit evidence planning: an examination of industry error characteristics", Auditing, Vol. 15 No. 1, pp. 71-86.

Owhoso, V.E., Messier, W.F. Jr and Lynch, J.G. Jr (2002), "Error detection by industry-specialized teams during sequential audit review", Journal of Accounting Research, Vol. 40 No. 3, pp. 883-900.

Owusu-Ansah, S. (2000), "Timeliness of corporate financial reporting in emerging capital markets: empirical evidence from the Zimbabwe Stock Exchange", Accounting and Business Research, Vol. 30 No. 3, pp. 241-254.

Praditya dan Fitriany (2013), “Analisis Faktor-Faktor yang MempengaruhiKetepatan Waktu Penyampaian Laporan Keuangan di Indonesia”, Simposium Nasional Akuntansi, Vol. XVI.

Reichelt, K.J. and Wang, D. (2009), "National and office-specific measures of auditor industry expertise and effects on audit quality", Journal of Accounting Research, Vol. 48 No. 3, pp. 647-686.

Sengupta, P. (2004), "Disclosure timing: determinants of quarterly earnings release dates", Journal of Accounting and Public Policy, Vol. 23 No. 6, pp. 457-482.

Sudana, I. (2011), "Manajemen Keuangan Perusahaan: Teori dan Praktik".

\section{Further reading}

Abdullah, S.-N. (2006), "Board composition, audit committee and timeliness of corporate financial reports in Malaysia", Corporate Ownership \& Control, Vol. 4 No. 2, pp. 33-45.

Abidin, S. and Ahmad-Zaluki, N.A. (2012), "Auditor industry specialism and reporting timeliness", Procedia - Social and Behavioral Sciences, Vol. 65, December, pp. 873-878.

Afify, H. (2009), "Determinants of audit report lag: does implementing corporate governance have any impact? Empirical evidence from Egypt", Journal of Applied Accounting Research, Vol. 10 No. 1, pp. 56-86.

Ahmed, K. (2003), "The timeliness of corporate reporting: a comparative study of South Asia", Advances in International Accounting, Vol. 16, pp. 17-43.

Akerlof, G.A. (1970), "The market for 'lemons': quality uncertainty and the market mechanism", The Quarterly Journal of Economics, Vol. 84 No. 3, pp. 488-500. 
AJAR

4,1

142

Alkhatib, K. and Marji, Q. (2012), “Audit reports timeliness: empirical evidence from Jordan”, Procedia - Social and Behavioral Sciences, Vol. 62, October, pp. 1342-1349.

Almutairi, A.R., Dunn, K.A. and Skantz, T. (2009), "Auditor tenure, auditor specialization, and information asymmetry", Managerial Auditing Journal, Vol. 24 No. 7, pp. 600-623.

Anshori, M. and Iswati, S. (2009), Metodologi Penelitian Kuantitatif, Universitas Airlangga, Surabaya.

Apadore, K. and Noor, M.M. (2013), "Determinants of audit report lag and corporate governance in Malaysia”, International Journal of Business and Management, Vol. 8 No. 15, p. 151.

Asthon, R.H., John, J.W. and Robert, K.E. (1987), "An empirical analysis of audit delay”, Journal of Accounting Research, Vol. 25 No. 2, pp. 275-292.

Badan Pengawas Pasar Modal Dan Lembaga Keuangan (2011), Penyampaian Laporan Keuangan berkala Emiten atau Perusahaan Publik Nomor X.K.2, Kementerian Keuangan Republik Indonesia, Jakarta.

Badan Pengawas Pasar Modal Dan Laporan Keuangan (2012), Penyampaian Laporan Tahunan Emiten Atau Perusahaan Publik, Kementerian Keuangan Republik Indonesia, Jakarta.

Baldacchino, P.J., Grech, L., Farrugia, K. and Tabone, N. (2016), "An analysis of audit report lags in Maltese companies", Contemporary Issues in Finance: Current Challenges from Across Europe, Emerald Group Publishing, pp. 161-182.

Bursa Efek Indonesia. Laporan Keuangan periode (2010-2016), available at: www.idx.co.id

Carcello, J.V., Hermanson, R.H. and McGrath, N.T. (1992), "Audit quality attributes: the perceptions of audit partners, preparers, and financial statement users", Auditing, Vol. 11 No. 1, p. 1.

Craswell, A.T., Francis, J.R. and Taylor, S.L. (1995), "Auditor brand name reputations and industry specializations", Journal of Accounting and Economics, Vol. 20 No. 3, pp. 297-322.

Dewi, I.C. and Hadiprajitno, P.B. (2017), "Pengaruh audit Tenure dan Kantor Akuntan Publik (KAP) Spesialisasi Manufaktur terhadap audit report lag (ARL)", Diponegoro Journal of Accounting, Vol. 6 No. 4, pp. 450-461.

Diastiningsih, N.P.J. and Tenaya, G.A.I. (2017), "Spesialisasi Auditor Sebagai Pemoderasi Pengaruh Audit Tenure dan ukuran KAP Pada audit report lag", E-Jurnal Akuntansi, pp. 1230-1258.

Dyer, J.C. and McHugh, A.J. (1975), "The timeliness of the Australian annual report", Journal of Accounting Research, Vol. 13 No. 3, pp. 204-219.

Eisenhardt, K.M. (1989), “Agency theory: an assessment and review”, Academy of Management Review, Vol. 14 No. 1, pp. 57-74.

Ettredge, M.L., Li, C. and Sun, L. (2006), "The impact of SOX Section 404 internal control quality assessment on audit delay in the SOX era", Auditing: A Journal of Practice \& Theory, Vol. 25 No. 2, pp. 1-23.

Fadhlan (2015), Pengaruh Audit Risk, Audit Complexity, dan Audit Expertise terhadap Audit Report Lag (Studi Kasus pada Perusahaan Manufaktur yang Terdaftar di Bursa Efek Indonesia Periode Tahun 2011-2013), Universitas Airlangga.

Fama, E.F. and Jensen, M.C. (1983), "Separation of ownership and control", The Journal of Law and Economics, Vol. 26 No. 2, pp. 301-325.

Ghozali, I. (2011), Aplikasi Analisis Multivariate dengan Program IBM SPSS 19, Edisi 5th, Badan Penerbit Universitas Diponegoro, Semarang.

Ghozali, I. and Chariri, A. (2007), Teori Akuntansi, Badan Penerbit Universitas Diponegoro, Semarang.

Goh, B.W. (2009), "Audit committees, boards of directors, and remediation of material weaknesses in internal control", Contemporary Accounting Research, Vol. 26 No. 2, pp. 549-579.

Gujarati, D. (2003), Basic Econometrics, 4th ed., New York, NY.

Harahap, S.S. (2005), Teori Akuntansi, PT RajaGrafindo Perkasa, Jakarta.

Horngren, C.T. and Harrison, W.T. (2007), "Akuntansi: Edisi Ketujuh Jilid”.

Ikatan Akuntan Indonesia (2014), Standar Akuntansi Keuangan, Salemba Empat, Jakarta. 
Institut Akuntan Publik Indonesia (2011), Standar Profesional Akuntan Publik, Salemba Empat, Jakarta.

Jama'an, J.A. (2008), "Pengaruh Mekanisme Corporate Governance dan Kualitas Kantor Akuntan Publik terhadap Integritas Informasi Laporan Keuangan (Studi pada Perusahaan Publik Di BEJ)", Program Pascasarjana Universitas Diponegoro.

Kieso, D.E., Weygandt, J. and Warfield, T.D. (2012), Intermediate Accounting, John Willey and Sons.

Knechel, W.R. and Payne, J.L. (2001), “Additional evidence on audit report lag”, Auditing: A Journal of Practice \& Theory, Vol. 20 No. 1, pp. 137-146.

Krishnan, J. (2005), "Audit committee quality and internal control: an empirical analysis", The Accounting Review, Vol. 80 No. 2, pp. 649-675.

Kross, W. and Schroeder, D.A. (1984), "An empirical investigation of the effect of quarterly earnings announcement timing on stock returns", Journal of Accounting Research, Vol. 22 No. 1, pp. 153-176.

Lee, H.Y., Mande, V. and Son, M. (2008), "A comparison of reporting lags of multinational and domestic firms", Journal of International Financial Management \& Accounting, Vol. 19 No. 1, pp. 28-56.

Lee, H.Y., Mande, V. and Son, M. (2009), "Do lengthy auditor tenure and the provision of non-audit services by the external auditor reduce audit report lags?", International Journal of Auditing, Vol. 13 No. 2, pp. 87-104.

Li, D. (2007), Auditor Tenure and Accounting Conservatism, Georgia Institute of Technology.

Mayhew, B.W. and Wilkins, M.S. (2003), "Audit firm industry specialization as a differentiation strategy: evidence from fees charged to firms going public", Auditing: A Journal of Practice \& Theory, Vol. 22 No. 2, pp. 33-52.

Menteri Keuangan (2008), Jasa Akuntan Publik, Kementerian Keuagangan Republik Indonesia, Jakarta.

Michael, C.J. and Rohman, A. (2017), "Pengaruh Audit Tenure dan Ukuran KAP terhadap Audit Report Lag dengan Spesialisasi Industri Auditor Sebagai Variabel Moderasi (Studi Empiris pada Perusahaan Manufaktur yang Terdaftar di Bursa Efek Indonesia tahun 2013-2015)”, Diponegoro Journal of Accounting, Vol. 6 No. 4, pp. 378-389.

Newton, J.D. and Ashton, R.H. (1989), "The association between audit technology and audit delay", Auditing-a Journal of Practice \& Theory, Vol. 8, pp. 22-37.

Ng, P.P. and Tai, B.Y. (1994), "An empirical examination of the determinants of audit delay in Hong Kong”, The British Accounting Review, Vol. 26 No. 1, pp. 43-59.

O'Reilly, D.M. and Reisch, J.T. (2002), "Industry specialization by audit firms: what does academic research tell us?", Ohio CPA Journal, Vol. 61 No. 3, pp. 42-42.

Otoritas Jasa Keuangan (2015), Pembentukan dan Pedoman Pelaksanaan Kerja Komite Audit, Otoritas Jasa Keuangan Republik Indonesia, Jakarta.

Pratama Rudyawan, A. and Nyoman Badera, I.D. (2009), "Opini audit going concern: Kajian berdasarkan model prediksi kebangkrutan, pertumbuhan perusahaan, leverage, dan reputasi auditor", Jurnal Ilmiah Akuntansi dan Bisnis, Vol. 4 No. 2.

Puat Nelson, S. and Norwahida Shukeri, S. (2011), "Corporate governance and audit report timeliness: evidence from Malaysia”, Accounting in Asia, Emerald Group Publishing, pp. 109-127.

Rachmawati, S. (2008), "Pengaruh Faktor Internal dan Eksternal Perusahaan Terhadap Audit Delay dan Timeliness", Jurnal Akuntansi dan Keuangan, Vol. 10 No. 1, pp. 1-10.

Rainsbury, E.A., Bradbury, M. and Cahan, S.F. (2009), "The impact of audit committee quality on financial reporting quality and audit fees", Journal of Contemporary Accounting \& Economics, Vol. 5 No. 1, pp. 20-33.

Rochmah Ika, S. and Mohd Ghazali, N.A. (2012), "Audit committee effectiveness and timeliness of reporting: Indonesian evidence”, Managerial Auditing Journal, Vol. 27 No. 4, pp. 403-424.

Rusmin, R., Rusmin, R., Evans, J. and Evans, J. (2017), "Audit quality and audit report lag: case of Indonesian listed companies”, Asian Review of Accounting, Vol. 25 No. 2, pp. 191-210.

Rustiarini, N.W. (2013), "Pengaruh Karakteristik Auditor, Opini Audit, Audit Tenure, Pergantian Auditor Pada Audit Delay", JINAH (Jurnal Ilmiah Akuntansi dan Humanika), Vol. 2 No. 2. 
AJAR

4,1

144

Saleh, R.S. (2004), "Studi Empiris Ketepatan Waktu Pelaporan Keuangan Perusahaan Manufaktur di Bursa Efek Jakarta", Jurnal Bisnis Strategi, Vol. 13 No. 1, pp. 67-80.

Spence, M. (1973), "Job market signaling”, The Quarterly Journal of Economics, Vol. 87 No. 3, pp. 355-374.

Sudaryanti, N. (2008), Faktor-Faktor yang Mempengaruhi Ketepatan Waktu Pelaporan Keuangan. (Skripsi), Universitas Diponegoro, Semarang.

Sultana, N., Singh, H., der Zahn, V. and Mitchell, J.L. (2015), “Audit committee characteristics and audit report lag”, International Journal of Auditing, Vol. 19 No. 2, pp. 72-87.

Tuanakotta, T.M. (2015), Audit Kontemporer, Salemba Empat, Jakarta.

Turley, S. and Zaman, M. (2004), "The corporate governance effects of audit committees", Journal of Management and Governance, Vol. 8 No. 3, pp. 305-332.

Utami, W. (2006), “Analisis determinan audit Delay Kajian Empiris di Bursa Efek Jakarta”, Bulletin Penelitian, Vol. 9.

Wang, J. and Song, L. (2006), "Timeliness of annual reports of Chinese listed companies", Journal of Chinese Economic and Business Studies, Vol. 4 No. 3, pp. 241-257.

Watts, R.L. and Zimmerman, J.L. (1983), "Agency problems, auditing, and the theory of the firm: some evidence", The Journal of Law and Economics, Vol. 26 No. 3, pp. 613-633.

Whittred, G. and Zimmer, I. (1984), "Timeliness of financial reporting and financial distress", Accounting Review, Vol. 59 No. 2, pp. 287-295.

Widyawati, A.A. and Anggraita, V. (2013), "Pengaruh Konvergensi, Kompleksitas Akuntansi, Dan Probabilitas Kebangkrutan Terhadap Timeliness Dan Manajemen Laba”, Jurnal Akuntansi dan Auditing Indonesia, Vol. 17 No. 2, pp. 135-155.

Yediel dan Sutaryo (2014), "Pengaruh Karakteristik Auditor terhadap Audit Delay Laporan Keuangan Pemerintah Daerah”, Simposium Nasional Akuntansi, Vol. XVI.

Zakkiyah, U.Z. (2014), “Analisis Penggunaan Model Zmijewski (X-Score) dan Altman (Z-Score) untuk Memprediksi Potensi Kebangkrutan (Studi pada Perusahaan Tekstil dan Garmen yang Terdaftar di (BEI) Bursa Efek Indonesia Periode 2009-2012)", Jurnal Administrasi Bisnis, Vol. 12 No. 2.

Zhang, Y., Zhou, J. and Zhou, N. (2006), “Audit committee quality, auditor independence, and internal control weaknesses”, Journal of Accounting and Public Policy, Vol. 26 No. 3, pp. 300-327.

Zmijewski, M.E. (1984), "Methodological issues related to the estimation of financial distress prediction models", Journal of Accounting Research, Vol. 22, pp. 59-82.

\section{Corresponding author}

Habiburrochman Habiburrochman can be contacted at: habib@feb.unair.ac.id

For instructions on how to order reprints of this article, please visit our website:

www.emeraldgrouppublishing.com/licensing/reprints.htm

Or contact us for further details: permissions@emeraldinsight.com 